\title{
Financial auditing and financial reporting for Romanian state-owned companies - modified opinions and observations
}

\author{
Costel Istrate ${ }^{\mathrm{a} 1}$ \\ alexandru Ioan Cuza University of Iași, Romania
}

\begin{abstract}
Starting with 2016, the Romanian authorities decided that 17 stateowned companies should use IFRS in their individual financial statements. The objective of this paper is to analyse how these companies have applied the accounting standards - before the transition to IFRS (2010-2017) - through the observations included in the reports delivered by the financial auditors. The main findings are: the presence of Big 4 auditors is quite limited, but in line with the situation of others categories of Romanian companies (especially the listed companies); the modified opinion are, by far, the most frequent (more than 78\%). The main justifications of the modified opinions are the non-observance of the accounting rules on the provisions, followed by problems in the measurement of the assets/liabilities, and the consequences of the prudence principle. Emphasis of matters paragraph is also very present in the audit reports: the main observations in these paragraphs is about the going concern matters ant about the dependence of the state owned companies on the decisions of some public authorities.
\end{abstract}

Keywords: state-owned companies, audit reports, modified opinions, emphasis of matter paragraph, financial reporting

JEL codes: M42, M41

\section{Introduction}

An important consequence of the state's presence in the economy is the existence of state-owned companies, either wholly-owned enterprises or companies of which the

\footnotetext{
${ }^{1}$ Corresponding author: Department of Accounting, Management Information Systems and Statistics, Alexandru Ioan Cuza University of Iași; Carol 1 Bd., no.22, +40740210637; email address: istrate@uaic.ro
} 
state it is the main shareholder. The extent of this presence depends on several variables, including economic policy promoted at some point by the public authorities (at all levels: national, regional and local). These policies are, in most cases, the result of electoral confrontation between programs and politicians. The latter often take into account political ideologies that may give the State a more or less important place in the control of certain areas of activity. In Romania (but also in the other countries of Central and Eastern Europe), after a few decades of almost total control of the state over the economy, the 1990s brought massive privatizations (especially after 1996 - for political reasons) which led to a sharp decline in the state's position as a shareholder. This trend towards the privatization of former state-owned companies has been accompanied by the creation of many new private entities. But the Romanian state has never completely renounced on its position as a major economic player. Moreover, all over the world, the state is more or less involved in business: Kowalski et al. (2013) found that the presence of the state in the economic sectors of many countries (including in developed countries) is significant and that, for example, state-owned firms hold an important place in the trade and in business takeovers in other countries (Karolyi \& Liao, 2017). Burkard (2009) finds that the state, even if it has waived participation, remains very important as a regulator.

The reputation of the state, as an economic actor, is not always a very good one. Shleifer and Vishny (1997: 768, cited by Guedhami et al., 2009), argue that, despite the fact that in theory these firms are subject to public control, in reality de facto control belongs to the bureaucrats, and the goals of the latter are not always to ensure the general well-being, but rather to satisfy their political, individual and/or group interests. In respect to the performances reported by companies, Wang and Shailer (2018) found that government ownership is associated with inferior performance.

The literature (Profiroiu \& Profiroiu, 2007; Kowalski et al., 2013) distinguishes, on the one hand, between state-owned enterprises that produce goods and public services of a collective nature and whose functioning does not rest necessarily on principles of financial profitability and, on the other hand, state-owned enterprises comparable to private entities, because it produces and sells goods and services in accordance with market principles.

All entities are subject to the general accounting and financial reporting requirements. There are even more binding obligations for these state-owned firms, because of the fact that they manage public money. Thus, in accordance with Romanian Law 544/2001 on free access to information of public interest, stateowned enterprises are assimilated to public authorities and institutions, and therefore obliged to respect a fairly strict regime of transparency. Among the information considered of public interest and which must be published by these companies are the financial resources, the budget and the balance sheet. As a result, in principle, the financial statements of these companies are available ex officio. The easiest way to meet this legal obligation is to put these documents on the Internet Sites. I do not 
propose to make an exhaustive analysis of these firms - it is impossible for us to identify them and to obtain the necessary information for all firms whose public authorities (central and/or local) are the sole or majority shareholders. The main selection criterion is to retain large state companies that appear in an order of the Minister of Public Finance (OMFP 666/2015) which impose the application of IFRS in their separate and consolidate (if applicable) financial statements. There are, in an appendix to this order 17 national companies. For comparability reasons, I add to this very limited sample the state-owned firms listed on the Bucharest Stock Exchange (BSE): there are 9 companies who apply IFRS since 2012 (on the regulated market) and another 14 who apply the Romanian Accounting Standards (RAS - on the alternative market AeRO). What interests us in the financial reports of these state firms are the audit reports that accompany the financial statements.

In this descriptive study, I try to highlight, through the opinions of financial auditors, how state-owned companies apply accounting standards. Since the opinions of the auditors of the 17 state firms are (very) mostly modified, the explanations of these modified opinions and the other observations included in the audit reports allow us to have a certain image of the most important difficulties encountered by these companies in the implementation of the accounting regulations. An important premise to be aware of is that these 17 companies are very large, have complex activities and therefore the organization of accounting and financial reporting are, themselves, very complex and require significant logistical and human resources ${ }^{\text {ii }}$. The financial reporting system for state-owned firms is considered very important by the OECD, which (according to Kowalski \& Perepechay, 2015) recommends for this category of companies the same obligations as for listed entities. Wang and Shailer (2018) propose that studies on the state owned companies listed on the financial market are more relevant, due to the availability of data and to the quality of the financial reporting.

To our knowledge, the analysis on the Romanian state-owned companies particularly focuses on the economic aspects or performance, and there are not so far to study the content of audit reports of these firms. In the international literature on this type of company, the most discussed themes concern the effects of privatizations on performance, the choice of auditors, financing, the presence on the financial markets, the evolution of the level of corruption, the earnings management etc. This study complements part of the research in this area and I am sure that it can be useful for a better understanding of the functioning of state-owned enterprises and that it can be used for specific decision-making factors and also for accounting standard setters.

The reminder of the study includes a literature review (section 2), a description of the methodology and sample (section 3) results and discussions (section 4), before concluding and presenting the references. 


\section{Literature review}

In OECD countries, the presence of state-owned companies, although significant ${ }^{\text {iii }}$ is less important than in emerging countries and is particularly evident in sectors such as energy, telecoms, transport and banks (Kowalski et al., 2013). Using data from Forbes Global 2000 (the largest 2,000 companies in 66 countries, including OECD countries), Kowalski et al. (2013) identify more than $10 \%$ of state-owned companies, firms with subsidiaries and own interests in 330,000 other companies. The figures differ from one country to another, with the top places being held by China, India and Russia. The overall sales of these state-owned companies are about $10 \%$ of the total sales of the top 2,000 Forbes companies. The dimensions of state-owned firms are analysed by Cuervo-Cazurra et al. (2014) who find that, in 2010, among the 100 largest multinationals, 19 belonged to the states. In Romania, according to a report published by an organization of the managers and of the investors (PIAROM \& ZF, 2017), the state-owned firms are (in 2015) in number of 1,095, compared to the active private firms, about 470,000 . Thus, with less than $0.2 \%$ of the total number of Romanian firms, state-owned companies generate 4\% (in 2014 and 2015) of the overall sales of Romanian firms, employ $7 \%$ of the workforce, have average wages as high as in the multinationals and achieve a productivity twice as low as private companies (and even three times lower than firms whose shareholders are mainly foreign).

The specific governance of state-owned firms presents important particularities compared to private firms (Kloviene \& Gimžauskiene, 2014). These particularities derive from the fact that the successive responsibilities in obtaining and monitoring the performance of these firms are more complex and involve actors such as: the executive direction, the board of directors, various state authorities, the government, the parliament. Under these conditions, it is not always easy to establish the precise users of the financial information provided by these companies, let alone the beneficiaries of their performance.

The financial presentation requirements of state-owned enterprises are often the same as for other firms operating in the same jurisdiction and under the same conditions. I have already shown that these state-owned firms have specific obligations of financial transparency because they manage public money. On the other hand, Havrylyshyn \& McGettigan (1999) found that the discipline of managerial labour markets may be weaker or absent under government ownership if managers are usually chosen for ideological or political reasons rather than their managerial ability.

The auditing standards state that the financial auditor must express an opinion on the financial statements of the audited firms. These opinions are modified or unmodified. The proportion of modified opinions differs from one country to another, from one 
period to another, from one category of firms to other categories (listed vs. unlisted, state vs. private, large vs smaller etc.), from one business sector to another. In the case of listed firms, the type of audit opinion depends on the auditor's observations during the engagement, but also on the position of the regulatory authorities. For example, in the United States, the SEC considers that a modified opinion means a failure of the firm in the application of the specific rules and, consequently, the modified opinions received by listed firms are $\operatorname{rare}^{\mathrm{iv}}$ (Cipriano et al., 2017).

The literature on audit opinions is rich, but most studies analyse listed firms, among which a minority belong to the state. The fact that large state-owned companies may have characteristics in common with listed private firms of similar size means that, at the level of audit reports, there are common elements regarding the justification of opinion and the determinants of modified opinions. Paananen (2016) warns us that the specificity of state-owned firms must be taken into account and comparisons with private firms should be made with caution. Paananen (2016) proposes to test the case of state firms (more precisely, municipal) the influence of certain determinants on the audit opinions: the level of profitability, solvency, liquidity indicators, the auditor's type (none of these determinants are confirmed), the length of the audit report, the size of the audit firm, the size of the firm audited (confirmed). In Romania, Bunget and Dumitrescu (2012) analyse the justifications for modified opinions, by accounting principle not respected, but their sample is limited to the clients of an audit firm.

\section{Methodology and sample}

OMFP 666/2015 establishes the list of Romanian state firms subject to the obligation to apply IFRS (see Appendix 1). I have already pointed out that, in my opinion, the main reason for this application is the influence of international financial organizations (WB and IMF). At the same time, there are recommendations in this regard in the OECD documents. Unlike Romanian companies listed on the regulated BSE market - which had very little time to prepare for transitions to IFRS - OMFP $666 / 2015$ sets a more generous timetable for the transition of the 17 state firms. Thus, for the 2016 and 2017 fiscal years (all of these firms close at December 31), companies keep their current accounts in RAS, prepare financial statements in RAS and restate these financial statements in order to obtain an IFRS set of financial statements. However, as of 2018, these companies are fully transitioning to IFRS, both in their current accounting and in the presentation of financial statements.

To achieve this objective, there was identified on the websites of these 17 companies, the accompanying financial statements and audit reports. The selected period is 2010 - 2017: there is very little information available from before this year: even for 2010, only 3 available audit reports could be found. Gradually, as we approach 2017, the number of available reporting increases (Table 1). 
The areas of activity of the companies studied are fairly well in the international average: Kowalski et al. (2013) finds that economic sectors where the state and most present in OECD countries are: support activities for the mining sector, civil engineering, land and air transport, coal mining, oil and gas. These findings are confirmed by Kwiatkowski and Augustynowicz (2015), for state-owned firms that appear in Fortune Global 500.

The data of interest in the audit reports identified for the 17 Romanian firms are as follows:

1. the auditor category: Big 4 vs. Non Big 4, but with the identification of auditors belonging to the latter category who are affiliated with international firms;

2. the type of opinion: unmodified vs. modified (qualified, disclaimer of opinion, adverse opinion);

3. the explanations proposed by the auditor to justify the modified opinion;

4. the existence, in the report, of an emphasis of matter paragraph and the justifications presented in this paragraph.

Based on these data, I propose to describe the way Romanian state-owned firms comply with accounting and financial reporting standards and to highlight the main findings that financial auditors made after their audit work. In the almost complete absence of other similar research (to our knowledge), I has chosen to compare the main results with data specific to state-owned companies listed on the BSE, both in the regulatory market and on a secondary market (AeRo). There will be no statistical treatment in this study, to establish relations between the various variables characteristic of Romanian state-owned companies.

\section{Results}

Audit reports are an important source of information for the users of financial statements. When the opinion is unmodified, users find in the reports the ready-made paragraphs that confirm the financial statements' compliance with applicable standards. On the other hand, in the case of a modified opinion, users (especially those with sufficient accounting knowledge) can quickly see what are the situations in which the application of the standards is not completely correct and/or the significant risks that may affect the performance of the entity. In all cases, the audit reports are supposed to contribute to a better appreciation of the financial and managerial performances of the firms analysed.

\subsection{Big 4 versus not Big 4}

To begin, there will be presented data on the categories of auditors who give opinions for the 17 state firms analysed in this study. As often in the literature, I separate the big auditors (Big 4) from the others (Non Big 4). This distinction is justified by the 
very common idea in the audit literature that the Big 4 ensure a better quality of the audit. This hypothesis is confirmed in some studies, but there are some authors who consider that Big 4 vs. Non Big 4 differences are not significant ${ }^{v}$. The approach is simple - counting the reports from the Big 4; in more sophisticated studies, the presence of the Big 4 is calculated by weighting the type of auditors to take into account the dimensions of the firms audited and arriving at values much higher compared to simple percentages. But in this study, the important dimensions of all the firms involved allow us to appreciate that the weighting would not lead to significantly different figures.

For the sample (see Table 1), the overall weight of $46.39 \%$ of Big 4 is not very suggestive, given the small number of observations for the first three years analysed. We can consider that the figures of the last years $(29.42 \%$ in 2017 and $37.50 \%$ in 2016) are more representative to describe the presence of Big 4 in the case of the Romanian companies in the sample. This situation is comparable to that presented by Guedhami et al. (2009) who find 34\% of Big 4 in a sample of 176 privatized state firms (in 32 countries, including 21 emerging); at the same time, Guedhami et al. (2009) find that the presence of the state as majority owner decreases the likelihood of using a Big 4 auditor.

Comparing the figures reported in Table 1 with the situation on the Romanian financial market leads to the following findings:

1. for the regulated market and for the period 2007-2017 (962 observations available, including firms whose activities are financial), the weight of Big 4 is $37 \%$ (it drops to $30 \%$ after the elimination of financial activities);

2. for the same regulated market and for the period analysed in this study (2010 - 2017: 698 observations), the weight of Big 4 is about 39\%;

3 . by retaining only state-owned firms listed on the regulated market ( 9 companies), the weight of Big 4 is more than $60 \%$ (61\% for the period $2007-2017 ; 63 \%$ for the period 2010-2017);

4. in the alternative market (AeRo), for the period 2010-2017 (1,978 observations), there is only $7 \%$ of Big 4 and no auditor of this category is found for the state-owned firms listed on this segment (14 companies for the period).

In all cases, the weight of the Big 4 is (much) lower than the situations that we could find in the literature, for other countries, especially developed. Still in Romania, Berinde and Groşanu (2013) found only 18\% of Big 4 for a sample of firms in the North West region. I can comment on the specific situation of Romania in the sense that the exposure on a large financial market (such as the regulated segment of the $\mathrm{BVB}$ ), the public exhibition by the dimensions and/or the obtaining of the financing from some international organizations (the case of large state-owned companies) can be decisive factors in choosing a Big 4, although the weight of this category of auditors is not yet very important. 
Table 1. Categories of auditors for Romanian state-owned firms in OMFP 666/2015

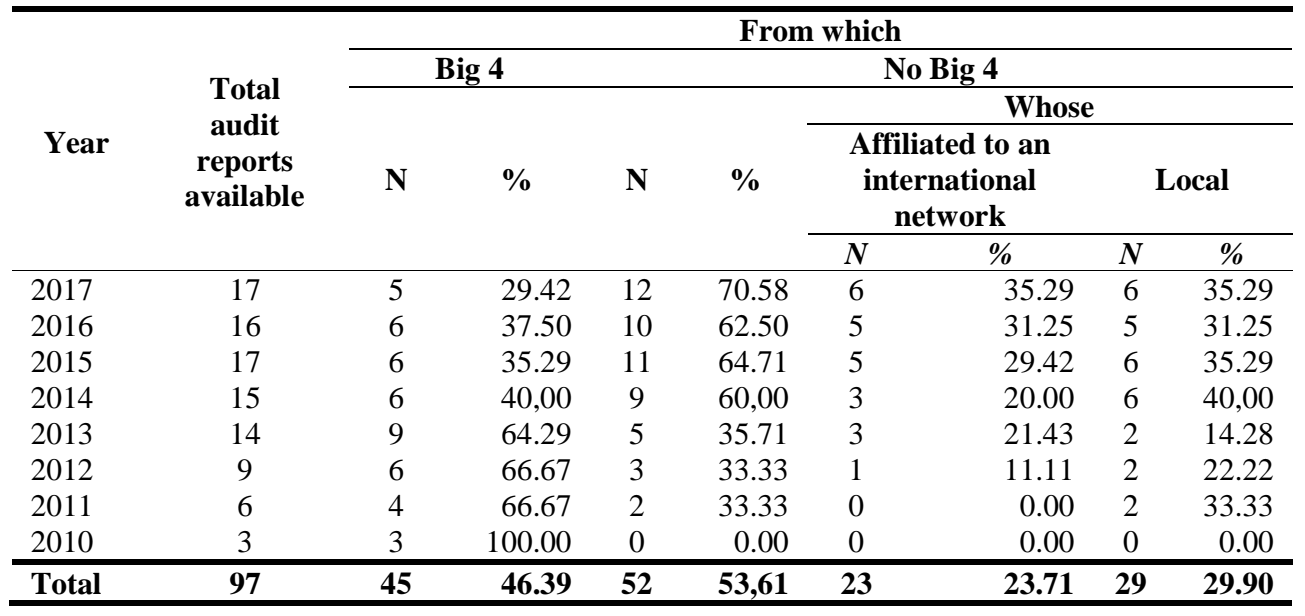

Francis et al. (2012) calculate the concentration of the audit market in 42 countries and, from more than 115,000 observations (for the period 1999-2007), identify around 43,000 reports issued by non-Big 4 auditors; that's over $63 \%$ of Big 4 . In the case of state-owned companies, the Chinese setting is particular, in the sense that the Big 4 presence is very limited ( $\mathrm{Su} \& \mathrm{Wu}, 2017)$; the explanation is that the state ownership being associated with a weaker demand for high-quality audits (Wang \& Shailer, 2018).

All the calculations presented take into account only two categories of auditors (Big 4 and non-Big 4). But, there are authors (notably in Romania) who suggest the classification of the auditors in several categories: Păunescu (2015) proposes 4 categories: Big 4, not Big 4 affiliated with international firms, other non-Big 4 and individual auditors. For the sample, we can add to the Big 4, the auditors internationally affiliated (BDO and PKF, more precisely) and we obtain 46.39\% + $23.71 \%=70.00 \%$ for the whole sample (more than $60 \%$ for the last years). This shows that the access of local audit firms to contracts offered by large state-owned firms (more than $30 \%$ in recent years) seems rather difficult.

\subsection{Types of opinions in the audit reports of the analysed state firms}

In the case of state-owned firms, users must have access to financial information by virtue of the public nature of these activities. It is interesting to see how public money is spent, how goods and services are produced. The peculiarities of these firms, the individual and collective interests of the managers of these firms and the bureaucracy that makes them work are all reasons for the introduction of an independent intermediary - the financial auditor - between the producer and the users of specific 
Financial auditing and financial reporting for Romanian state-owned companies modified opinions and observations

financial information. The role of the auditor is to verify the extent to which the financial statements are prepared in accordance with accounting standards and to express an opinion on how the financial statements fairly reflect the financial position and the performance of the audited entity. A report that contains an unmodified opinion and contains no comments allows the user to be confident that the financial statements represent what they are meant to represent. In Table 2, I have centralized the various opinions expressed by the auditors of the firms analysed.

Table 2. Types of opinions in the audit reports of Romanian state-owned companies appearing in the OMFP 666/2015

\begin{tabular}{cccccccr}
\hline \multirow{2}{*}{ Year } & \multirow{2}{*}{$\begin{array}{c}\text { Number } \\
\text { of observations }\end{array}$} & \multicolumn{2}{c}{$\begin{array}{c}\text { Unmodified } \\
\text { opinions }\end{array}$} & \multicolumn{2}{c}{$\begin{array}{c}\text { Qualified } \\
\text { opinions }\end{array}$} & \multicolumn{2}{c}{$\begin{array}{c}\text { Disclaimer } \\
\text { of opinion }\end{array}$} \\
\cline { 3 - 8 } & $\mathbf{N}$ & $\mathbf{\%}$ & $\mathbf{N}$ & $\mathbf{\%}$ & $\mathbf{N}$ & $\mathbf{\%}$ \\
\hline 2017 & 17 & 4 & 23.53 & 12 & 70.59 & 1 & 5.88 \\
2016 & 16 & 3 & 18.75 & 12 & 75.00 & 1 & 6.25 \\
2015 & 17 & 4 & 23.53 & 12 & 70.59 & 1 & 5.88 \\
2014 & 15 & 3 & 20.00 & 11 & 73.33 & 1 & 6.67 \\
2013 & 14 & 3 & 21.43 & 9 & 64.29 & 2 & 14.28 \\
2012 & 9 & 2 & 22.22 & 6 & 66.67 & 1 & 11.11 \\
2011 & 6 & 2 & 33.33 & 4 & 66.67 & 0 & 0.00 \\
2010 & 3 & 0 & 0.00 & 3 & 100.00 & 0 & 0.00 \\
\hline Total & $\mathbf{9 7}$ & $\mathbf{2 1}$ & $\mathbf{2 1 . 6 4}$ & $\mathbf{6 9}$ & $\mathbf{7 1 . 1 4}$ & $\mathbf{7}$ & $\mathbf{7 . 2 2}$ \\
\hline
\end{tabular}

The weight of the modified opinions is extremely high - about $78 \%(71.14+7.22)$ - even taking into account only the last years. This allows us to appreciate that, in the opinion of the auditors, there are significant risks that the financial statements contain significant information that is not fully compliant with the accounting framework applicable by the Romanian state-owned companies. For other firms whose audit reports are available, we found the following figures:

1. for companies listed on the regulated market of the BVB, for the period 2007-2017 (962 observations available), we have 27.03\% of modified opinions; of these firms, the state-owned ones (85 observations) show $35.29 \%$ of modified opinions;

2. on the second segment of the BVB (AeRo), where are listed small firms, for the period 2010-2017 (1,978 observations), I found only $23,31 \%$ of modified opinions (17.85\% for the state owned firms - 112 observations).

The data shows us that the 17 state-owned firms that should apply IFRS face significant difficulties in complying with Romanian accounting standards, which are reflected in the majority of their auditors' opinions.

For a comparison with state firms from another country, I found the analysis of Paananen (2016) who finds that $31 \%$ of Finnish municipal firms receive modified 
opinions. Wang et al (2008) found about $12 \%$ of modified opinion in the case of some state-owned companies from China, whit a smaller probability to issue a modified opinion for the small local auditors.

Modified opinions (in all their forms) are often presented in the literature as proof of the auditor's independence and, therefore, of the quality of the audit. In the table 3, I presented the types of opinions by category of auditors (Big 4 vs. others). There too, we can consider that the last years are the most representative.

Table 3. Type of opinion by categories of auditors

\begin{tabular}{cccccc}
\hline \multirow{2}{*}{ Year } & $\begin{array}{c}\text { Modified opinions } \\
\text { (qualified and }\end{array}$ & \multicolumn{4}{c}{ From which } \\
\cline { 3 - 6 } & disclaimer of opinion) & $\mathbf{N}$ & $\mathbf{6}$ & $\mathbf{N}$ & \% \\
\cline { 2 - 6 } 2017 & $12+1=13$ & 4 & 30.74 & 9 & 69.23 \\
2016 & $12+1=13$ & 6 & 46.15 & 7 & 53.85 \\
2015 & $12+1=13$ & 6 & 46.15 & 7 & 53.85 \\
2014 & $11+1=12$ & 6 & 50.00 & 6 & 50.00 \\
2013 & $9+2=11$ & 8 & 72.73 & 3 & 27.27 \\
2012 & $6+1=7$ & 6 & 85.71 & 1 & 14.29 \\
2011 & $4+0=4$ & 4 & 100.00 & 0 & 0.00 \\
2010 & $3+0=3$ & 3 & 100.00 & 0 & 0.00 \\
\hline Total & $\mathbf{6 9 + 7}=\mathbf{7 6}$ & $\mathbf{4 3}$ & $\mathbf{5 6 . 5 8}$ & $\mathbf{3 3}$ & $\mathbf{4 3 . 4 2}$ \\
\hline
\end{tabular}

As we could expect, the weight of the modified opinions issued by Big 4 (more than $56 \%$ ) is greater than their weight in the total number of auditors. This confirms, in a way, that Big 4 prove more independent than others. But, these data must be completed with an important detail: among the non-Big 4, there are those affiliated with international firms (23 observations) and, put together, the modified opinions of these two categories of auditors represent $86.84 \%$ of all modified opinions. As a result, local auditors (29 observations) are much less likely to give modified opinions: 10 , or $13.16 \%$ from the total number of the modified opinions. Or, perhaps, local auditors have come across state-owned firms that ensure more compliance with standards. Păunescu (2015) comments on a similar situation and explains the unmodified opinions of local (Romanian) auditors through pressure from the management of the audited firms and the interest of these auditors in keeping their clients.

\subsection{Justifications of the modified opinions for the analysed state firms}

The auditor issuing a modified opinion must justify this qualification specifying the aspects that it considers that the presentation is wrong or where it has not obtained sufficient audit evidence. ISA 705 (2012) states that modified opinions are issued in the following situations: 
1. qualified opinion: the auditor determines that the financial statements as a whole contained misstatements, which are material, but not pervasive or the auditors is unable to obtain sufficient appropriate audit evidence to conclude that the financial statements as a whole do not contain any misstatements significant;

2. adverse opinion: the auditor concludes, after obtaining sufficient and appropriate evidence, that misstatements, individually or in aggregate, have both a material and pervasive character in the financial statements;

3. disclaimer of opinion: the auditor is unable to obtain sufficient appropriate audit evidence on which to formulate his opinion and concludes that the potential impact on the financial statements of undetected misstatements could be both material and pervasive.

In the reports analysed, 69 of the modified opinions are qualified opinions, while in 7 cases it is disclaimer of opinion. The paragraphs in which the auditors justify the modified opinions include one or more explanations, which were grouped into a few major themes (Table 4, in descending order of the frequency of appearance, for the items with more than five appearances). It is obvious that by this codification I have lost some of the auditors' message, but this has allowed us to do minimal quantitative processing. In each individual report, we could find between one and 16 different explanations for the modified opinion.

I have not found in the literature any study on this type of justification; therefore, I will compare the results with what has already been noted for listed companies. Istrate (2017) shows that, for Romanian firms listed on the BSE regulated market, the main explanations of the modified opinions refer to revaluations of fixed assets, provisions and items relating to measurement and to other assets/liabilities in the closing works. Bunget and Dumitrescu (2012) analyses the justifications for modified opinions by grouping them by accounting principle; they observe that most explanations concern (in descending order) the principle of prudence, the comparability, the accrual accounting and the going concern assumption.

For the firms analysed in this study, unlike for the listed Romanian companies, the revaluation of the fixed assets does not represent the first explanation which justifies the modified opinions. In fact, it is the application of the prudence principle (which joins the results of Bunget \& Dumitrescu, 2012) that is at issue in the judgments made by the auditors: six of the first ten explanations concern the non-consideration of certain risks, impairments and depreciations. To this is added the doubtful accounting of certain assets/liabilities and/or revenues and expenses, as well as the classification of these items for presentation in the financial statements. 
Table 4. Explanations of the modified opinions in the audit reports of Romanian state-owned firms in OMFP 666/2015

\begin{tabular}{lc}
\hline \multicolumn{1}{c}{ Explanation $^{v i}$} & $\begin{array}{c}\text { Frequency } \\
\text { of the appearance }\end{array}$ \\
\hline 1. Insufficient provisions or other difficulties in estimating provisions & 36 \\
2. Recognition of certain assets and/or liabilities & 30 \\
3. Insufficient attention paid to depreciation of fixed assets & 28 \\
4. Existence of litigation that may have adverse effects on the entity & 26 \\
5. Insufficient consideration of future obligations towards employees & 22 \\
6. Accounting for certain revenues and expenses & 19 \\
7. Revaluation of fixed assets & 18 \\
8. Inventory impairment & 16 \\
9. Receivables impairments & 14 \\
10. Non-participation of the auditor on the closing works & 14 \\
11. Incorrect estimate of some other depreciation & 10 \\
12. Approximate application of accounting rules for error correction & 10 \\
13. Problems in the levels of certain indicators imposed by the banks so & 9 \\
that the credits remain in the long term & 9 \\
14. Incorrect presentation of certain assets/liabilities & 9 \\
15. Deficiencies in the confirmation of the balances of receivables and \\
liabilities at closing date \\
16. Existence of legal problems (other than litigation) for the entity and/or \\
for members of management \\
17. Insufficient provisions for the restauration of some land \\
18. Other elements concerning the organization and the progress of closing \\
work \\
\%
\end{tabular}

The auditor's opinion may have some influence on users, although in the case of state-owned firms, user decisions often take into account other criteria than the performance displayed or compliance with accounting standards. Thus, the management of the audited entity would have an interest in the opinion being unmodified. Managers can arrive at this result by correcting the aspects observed by the auditors, but also by applying the technique that the literature calls opinion shopping, that is to say the change of the auditor having expressed a modified opinion. I counted the auditor changes in the sample and the impact of these changes is reported in Table 5 (it's not about the rotation of the partner, but about the audit firm). Among the 17 firms analysed, 12 had two or more changes in auditors during the analysed period: 6 firms changed once the auditor, 6 firms changed twice and 1 firm changed the auditor 3 times.

From the data in Table 5, we observe that, despite a significant rotation of the auditors, the effects on the audit opinion are not significant - only 4 cases of change of opinion, and only one form a modified to an unmodified opinion. We can 
Financial auditing and financial reporting for Romanian state-owned companies modified opinions and observations

conclude, with all the risks that derive from a limited sample - that the possible hypothesis of opinion shopping is not confirmed in the case of Romanian stateowned companies - Păunescu (2015) comes to a similar conclusion for firms listed on the BSE).

Table 5. Rotation of auditors by the analysed state-owned firms

\begin{tabular}{lccc}
\hline & $\begin{array}{c}\text { Number } \\
\text { of }\end{array}$ & $\begin{array}{c}\text { Change of opinion following the } \\
\text { auditor's change }\end{array}$ \\
\cline { 3 - 4 } Sense of the rotation & observations & $\begin{array}{c}\text { From a } \\
\text { modified } \\
\text { opinion to an } \\
\text { unmodified } \\
\text { opinion }\end{array}$ & $\begin{array}{c}\text { From an } \\
\text { unmodified } \\
\text { opinion } \\
\text { to a modified } \\
\text { opinion }\end{array}$ \\
\hline From Big 4 to Big 4 & 5 & - & 1 \\
From Big 4 to non-Big 4 & 8 & 1 & - \\
From non-Big 4 to Big 4 & 1 & - & 2 \\
From non-Big 4 to non-Big 4 & 7 & - & - \\
\hline $\begin{array}{l}\text { Total changes } \\
\text { of auditors }\end{array}$ & $\mathbf{2 1}$ & $\mathbf{1}$ & $\mathbf{3}$ \\
\hline
\end{tabular}

\subsection{Explanations in the emphasis of matters paragraphs from the audit reports of the analysed state-owned companies}

The international standard ISA 706 Emphasis of matter paragraphs and other matter paragraphs in the independent auditor's report states that if the auditor considers it necessary to draw the attention of the users to a matter presented or mentioned in the financial statements which, according to its own judgment, is of such importance that it is essential for their understanding of the financial statements or it considers that users' attention should be drawn to aspects that do not appear in the financial statements that may be important in terms of understanding the audit process and the audit report, the auditor shall include in his audit report a paragraph provided that he has obtained sufficient and appropriate evidence that the item presented or referred to in the financial statements does not include significant anomalies.

This type of paragraph is very common in audit reports issued for Romanian firms. In the Table 6, I centralized the information on the presence of such a paragraph, by category of auditor and type of opinion. For reasons of comparability, I have chosen to continue the presentation in parallel of the specific situation to the Romanian listed companies. Istrate (2017) finds for the BSE regulated market that the main explanations included in this paragraph concern: going concern matters (the most important, by far), items related to tax obligations and litigation, (non) consideration 
of certain other risks, other litigation, transactions with related parties, exposure to a single customer or a single business, provisions, revaluation and depreciation of fixed assets and other assets.

Table 6. Presence of emphasis of matter paragraphs in audit reports

\begin{tabular}{|c|c|c|c|c|}
\hline & Elements & $\begin{array}{c}\text { State- Owned } \\
\text { firms } \\
\text { (OMFP } \\
\text { 666/2015) }\end{array}$ & $\begin{array}{c}\text { Companies } \\
\text { listed on the } \\
\text { BSE - the } \\
\text { market } \\
\text { regulated }\end{array}$ & $\begin{array}{c}\text { Companies } \\
\text { listed on the } \\
\text { BSE - the } \\
\text { AeRo } \\
\text { segment }\end{array}$ \\
\hline \multirow{2}{*}{\multicolumn{2}{|c|}{ Period }} & $2010-2017$ & $2007-2017$ & $2010-2017$ \\
\hline & & 98 & 962 & 1,978 \\
\hline \multirow{3}{*}{$\begin{array}{l}\text { Reports that } \\
\text { contain an } \\
\text { emphasis of } \\
\text { matter } \\
\text { paragraph }\end{array}$} & $\begin{array}{l}\text { Total, from } \\
\text { which }\end{array}$ & $72(73.47 \%)$ & $287(29.83 \%)$ & $669(33.82 \%)$ \\
\hline & $\begin{array}{l}\text { associated with } \\
\text { unmodified } \\
\text { opinions }\end{array}$ & $16(22.22 \%)$ & $159(55.40 \%)$ & $458(68.56 \%)$ \\
\hline & $\begin{array}{l}\text { associated with } \\
\text { modified } \\
\text { opinions }\end{array}$ & $56(77.78 \%)$ & $128(44.60 \%)$ & $211(31.54 \%)$ \\
\hline
\end{tabular}

Like the firms listed on the regulated market (Istrate, 2017), the first explanation presented by the auditors in this paragraph section are related to the going concern issues, but unlike the listed firms, this explanation is joined by a specific aspect to state-owned firms: the dependence of public policies and decisions made by various state authorities that establish, for example, tariffs or other matter related to the environment, investments etc. (Table 7). Another common explanation is for provisions, whether related to employee profits or litigation.

Verifying the management's assertions of going concern is an important task for the auditor. It should be noted that going concern does not appear in any of the reports studied as a justification for the modified opinion and is only highlighted in the emphasis of matter paragraph. This situation is due, probably (and here I join Paananen, 2016), to the fact that the companies analysed are state-owned and that the State will not let them go bankrupt, because they carry out business activities of public interest, it employs a lot of people and, often, are big to fail. Moreover, Romania has a recent rich history of rescue of some state-owned firms, considered strategic and without any consideration for financial indicators that are largely negative. For example, on the regulated market, there is a state-controlled entity whose equity has been highly negative (with a few exceptions) since 2000 and which is still operating and which is still listed on the financial market. 
Financial auditing and financial reporting for Romanian state-owned companies modified opinions and observations

Table 7. Justifications of observation paragraphs

\begin{tabular}{lc}
\hline \multicolumn{1}{c}{ Explanation } & $\begin{array}{c}\text { Frequency } \\
\text { of appearance }\end{array}$ \\
\hline Going concern matters & 30 \\
Dependence on public policies, decisions of public authorities & 30 \\
Provisions & 14 \\
Restructuring of the firm & 14 \\
Litigations & 12 \\
Problems of a legal nature for the firm or for the members of the & 10 \\
management & 9 \\
Difficulties in the relationship with the tax authorities & 7 \\
Existence of environmental problems & 6 \\
Impairment of fixed assets & 6 \\
Revaluation & 5 \\
Approximate accounting recognition for certain assets and/or liabilities & 3 \\
Not enough attention in calculating and accounting for benefits granted & 2 \\
to employees & 1 \\
The company depends on commercial relations with a single partner & 1 \\
Related parties & 1 \\
Impairment of receivables & 9 \\
The auditor did not participate in the inventory work & \\
\hline
\end{tabular}

\section{Conclusions}

The state is present as a shareholder of some companies in many countries, including in developed countries. State-owned companies must fulfil the general accounting and financial reporting requirements and, in addition, because they are publicinterest entities, must transmit this information to users, in the interests of financial transparency (otherwise imposed by law). At the same time, the financial statements of these firms need to be audited, so that users can see how firms comply with specific accounting standards. An order from the Romanian Minister of Public Finance (OMFP 666/2015) requires 17 large state-owned companies to apply IFRS from 2016 (by restatement of information obtained applying RAS for 2016 and 2017 and effective application of IFRS in accounting current from 2018). I selected these firms and, before analysing the impact of the transition to IFRS, I studied the audit reports for the 2010-2017 period, in order to identify the main explanations offered by the auditors to justify their opinion and the main observations included in the specific paragraph.

The first results relate to the presence of Big 4 in the list of auditors of state firms (97 observations). The average is $46 \%$, but because the observations for the last part of the analysed period are more complete, we consider that a figure of about 30-35\% would be more credible. This weight of Big 4 is not far from the results for Romanian firms listed on the regulated market. To complete these results, it should be said that, 
among non-Big 4, there are some who belong to international audit firms, which means that the weight of local auditors is $29.90 \%$.

The audit opinions expressed by the auditors of the 17 state firms are mostly modified $(78.36 \%)$, which means that the auditors have detected significant risks regarding the information provided in the financial statements and that compliance with the accounting framework is not fully acquired. This proportion of modified opinions is very important compared to the other studies I have had access to. For example, for firms listed on the Romanian financial market (BSE), the modified opinions represent about $27 \%$ (for the regulated market) and about $23 \%$ for the AeRo segment. The main justifications for these modified opinions concern: provisions, recognition of certain assets/liabilities, impairment of fixed assets, litigation, recognition of employee benefits, recognition of other income and expenses, revaluation of fixed assets etc. Overall, most explanations refer to aspects related to closing works. I have found that the possible hypothesis of opinion shopping is not confirmed in the case of the firms in the sample.

In analysing the audit reports of the state-owned firms, I also identified the emphasis of matters paragraphs - also very numerous $(73.47 \%)$. The most frequent elements that appear in these paragraphs are the going concern and the exposure of the state firms to the decisions of the public authorities. Other topics are: provisions, the effects of restructuring, involvement in litigation, the existence of legal and tax problems, etc.

The main limitations of this study are the limited number of observations in the sample, the exclusively descriptive nature of the analysis and the fact that I did not correlate the variables extracted from the audit reports and other variables that characterize the firms considered.

The most appropriate future research directions are precisely the identification of correlations between variables specific to audit reports and other variables, the introduction of indicators of audit quality in correlations with the quality of the financial reporting. Another direction of research may concern the explanations given by the auditors of the firms selected in the sample in the paragraph of justification of appreciations (KAM - key audit matters), like in some other studies (Barbe \& Rimbault, 2015 or Moreau, 2017). The transition of state firms analysed to IFRS also opens up a new field of research on this type of firm.

\section{References}

Barbe, O. \& Raimbault, S. (2015) "La justification des appréciations améliore-t-elle la valeur du rapport d'audit?", Available on-line at https://documents.bsbeducation.com/pdf/cig2014/ACTESDUCOLLOQUE/BARBE_RAIMBAUL T.pdf (accessed at 15 December 2017) 
Berinde, S. \& Groşanu, A. (2013) "Particularities concerning the beneficiaries of audit services provided by Big 4 companies: evidence from Romania", Annales Universitatis Apulensis Series Oeconomica, vol. 15, no. 2: 483-492

Bunget, O. C. \& Dumitrescu, A. C. (2012) "A Study on the Relationship between Audit Opinion and Accounting Principles", Audit Financiar, vol. X, no. 1: 6-11

Cameran, M., Prencipe, A. \& Trombetta, M. (2016) "Mandatoory audit firm rotation an audit quality", European Accounting Review, vol. 25, no. 1: 35-58

Cipriano, M. Hamilton, E. L. \& Vandervelde, S. D. (2017) "Has the lack of use of the qualified audit opinion turned it into the "Rotten Kid" threat?", Critical Perspectives on Accounting, vol 47: 26-38

Cuervo-Cazurra, A., Inkpen, A., Musacchio, A. \& Ramaswamy, K. (2014) "Governments as owners: State-owned multinational companies", Journal of International Business Studies, vol. 45, no. 8: 919-942

DeAngelo, L. E. (1981) “Auditor size and audit quality”, Journal of Accounting and Economics, vol. 3, no. 3: 183-199

Francis, J. R., Michas, P. N. \& Seavey, S. E. (2012) "Does audit market concentration harm the quality of audited earnings? Evidence from audit markets in 42 countries", Contemporary Accounting Research, vol. XX, no. $\mathrm{X}: 1-31$

Guedhami, O., Pittman, J. A. \& Saffar, W. (2009) "Auditor choice in privatized firms: Empirical evidence on the role of state and foreign owners", Journal of Accounting and Economics, vol. 48, no. 2-3: 151-171

Havrylyshyn, O., D. \& McGettigan (1999) "Privatization in transition countries: A sampling of the literature", IMF Working Paper No. 99/6 (available on-line at https://www.imf.org/en/Publications/WP/Issues/2016/12/30/ Privatizationin-Transition-Countries-A-Sampling-of-the-Literature-2879, accessed at 12 aprilie 2018

Istrate, C. (2017) "Justifications for the modified opinions and for other observations in the audit reports of Romanian listed companies", paper presented on the $12^{\text {th }}$ AMIS Conference, Bucharest, 7-9 June 2017 (available on-line at https://amis.ase.ro/2017/docs/AMIS2017Proceedings.pdf, accessed at 12 April 2018)

Karolyi, G. A. \& Liao, R. C (2017) "State capitalism's global reach: Evidence from foreign acquisitions by state-owned companies", Journal of Corporate Finance, vol. 42: 367-391

Kloviene, R. \& Gimžauskiene, E. (2014) "Performance measurement model formation in state-owned enterprises", Procedia - Social and Behavioral Sciences, vol. 156: 594-598

Kowalski, P., Buge, M., Sztajerowska, M. \& Egeland, M. (2013) "State-Owned Enterprises - trade effects and policy implications", OECD Trade Policy Papers, no. 147, OECD Publishing, Paris (http://dx.doi.org/10.1787/ 5k4869ckqk7l-en) 
Kowalski, P. \& Perepechay, K. (2015) "International Trade and Investment by State Enterprises", OECD Trade Policy Papers, no. 184, OECD Publishing, Paris. (http://dx.doi.org/10.1787/5jrtcr9x6c48-en)

Kwiatkowski, G. \& Augustynowicz, P. (2015) "State-owned enterprises in the global economy - analysis based on Fortune Global 500 list", TIIM Joint International Conference 2015 (available on-lilne at http://www.toknowpress. net/ISBN/978-961-6914-13-0/papers/ ML15-353.pdf, accessed at 25 August 2017)

Lobo, G., Paugam, L., Zhang, D. \& Casta, J. F. (2017) "The effect of joint auditor pair composition on audit quality: evidence from impairment tests", Contemporary Accounting Research, vol. 34, no. 1: 118-153

Ministerul Finanțelor (2015) "Ordinul ministrului finanțelor publice nr. 666 din 9 iunie 2015 privind aplicarea Reglementărilor contabile conforme cu Standardele internaționale de raportare financiară de către unele entităţi cu capital de stat" [Order of the Ministry of Public Finance no. 666 from 9 June 2015 concerning the application of accounting regulations conforming with international fianncial reporting standards by some companies with state participation], Monitorul Oficial, no. 442/ 22 June 2015

Moreau, J. (2017) "Les justifications d'appréciation du commissaire aux comptes (et les pratiques internationales assimilées): revue de littérature, analyse des pratiques et perspectives de recherché", 38ème Congrès annuel de l'Association Francophone de Comptabilité, Poitiers

Paananen, M. (2016) "Modified audit reports in the case of joint municipal authorities: Empirical evidence from Finland", International Journal of Auditing, vol. 20, no. 2: 149-157

PIAROM \& ZF (Patronatul Investitorilor Autohtoni și Ziarul Financiar) (2017) "Capitalul privat românesc [The Romanian Private Capital]", available online at https://www.piarom.ro/wp-content/uploads/2017/02/brosuraPIAROM-ianuarie-2017.pdf?x76754 (accessed at 13 novembre 2017)

Păunescu, M. (2015) "The Romanian audit market structure in case of listed companies and the impact of adopting IFRS", Procedia Economics and Finance, vol. 32: 686-693

Profiroiu, A. \& Profiroiu, M. (2007) "Cadrul de analiză a performanțelor sectorului public" [Framework for the performance analysis in the public sector], Economie Teoretică şi Aplicată, no. 1 (506): 41-50

Sirois, L. P., Marmousez, S. \& Simunic, D. A. (2016) "Proposition d'une nouvelle approche de la relation entre la taille de l'auditeur et la qualité de l'audit : l'importance de la technologie d'audit', Comptabilité - Contrôle - Audit, tome 22, vol. 3: 111-144

$\mathrm{Su}, \mathrm{X} . \& \mathrm{Wu}, \mathrm{X}$. (2017) "Public discolsure of audit fees and bargaining power between the client and the auditor: evidence for China", The International Journal of Accounting, vol. 52, no. 1: 64-76 
Financial auditing and financial reporting for Romanian state-owned companies modified opinions and observations

Wang, K. T. \& Shailer, G. (2018) "Does ownership identity matter? A meta-analysis of research on firm financial performance in relation to Government versus private ownership", Abacus, vol. 54, no. 1: 1-35

${ }^{\mathrm{i}}$ In 2015, the Romanian Minister of Public Finance issued order 666/2015, which requires some state-owned companies (the largest) to convert to IFRS in their individual accounts. The rationale for this decision is the need for more transparency and comparability in the financial reporting of these companies. Another explicit explanation lies in the recommendations of the international financial organizations (World Bank and International Monetary Fund) and here I find, in fact, the main motivation for the mandatory application of IFRS in Romania, in the individual accounts of companies (European regulations limit the mandatory application of IFRS to the consolidated financial statements of listed groups).

ii Kowalski et al. (2013) find that the accounting and auditing standards applicable to stateowned enterprises are the same as for other companies, but that state-owned firms have to undergo other controls, from specific authorities. In Romania, these additional controls may come from the Romanian Court of Accounts, from the government control bodies and/or the different ministries.

iii Kwiatkowski and Augustynowicz (2015), based on the top Fortune Global 500, found 5\% of state-owned firms in developed countries, with France and Germany very well represented. The trend is on the rise.

iv The cited authors identify 11 modified opinions, for the period 2000-2015, for all firms registered with the SEC!

$v$ The first explanations of the better quality of the audits carried out by the Big 4 consist in their greater independence and competence (the characteristics proposed by DeAngelo, 1981). Thus, it is argued that the Big 4 provide quality audits to avoid risks that are more significant for them, arising from the loss of reputation and from financial losses (Sirois $e t$ al., 2016, Cameran et al., 2016, Lobo et al., 2017). Other explanations relate to the resources available to the Big 4, both human and logistical and training. Francis et al. (2012) establish, on a statistical basis, that the audit is of a better quality in countries where at least two of the Big 4 dominate the market relatively equally, and this quality is manifested both in the reports issued by the Big 4, only for those issued by non-Big 4 .

vi The explanations appearing 5 times or less than 5 times are: The absence of a written statement from the management of the firm, difficulties in the comparability of the information provided in the financial reports, use of grants outside the framework of contracts, other difficulties in the valuation at closing of certain assets and/or liabilities, difficulties in evaluating revenue and expenses, incorrect classification of certain revenues/charges, elements relating to the calculation and declaration of certain tax obligations and other problems in the relationship with the tax authorities, difficulties in valuing assets/liabilities other than at the date losing, overly optimistic estimation of securities held in subsidiaries, existence of transactions that the auditor qualifies as abnormal, problems in establishing and controlling the tariffs charged to customers, calculation and granting of discounts under conditions not provided for in the documents provided by the entities, difficulties in calculating the costs of certain products and services, problems with funding from European bodies, the entity is in insolvency. 